\title{
Echo miłej przyjaźni. Drobiazg wierszowany wydobyty z teki dawno zapomnianych rękopisów
}

\section{Wojciech Kaliszewsi}

ORCID: 0000-0002-68I4-2I58

(Instytut Badań Literackich PAN, Warszawa)

W zasobach rękopiśmiennych Biblioteki Litewskiej Akademii Nauk, czyli dawnej Biblioteki Wróblewskich w Wilnie, natrafiłem na cienką i skromną kopertę oznaczoną sygnaturą BF 215I, zawierającą odpis wiersza sygnowanego nazwiskiem Ignacego Szadurskiego pod tytułem Na dokończenie Biblioteki Collegium Nobilium Societatis Iesu ${ }^{\mathrm{I}}$. Utwór jest datowany na rok I770. Autorem odpisu był Wacław Gizbert Studnicki², znany wileński archiwista i bibliofil, który ofiarował go w roku I9ı2 - roku założenia Biblioteki Wróblewskich w Wilnie - Tadeuszowi Wróblewskiemu ${ }^{3}$, rzeczywistemu twórcy Biblioteki, z okazji jego imienin, przypadających na 28 października. Tekst został opatrzony przez ofiarodawcę tytułowym adresem, zachowującym poetykę i stylistykę właściwą adresom wierszy okolicznościowych. Tytuł zawiera określenie „aplauz tryumfalny”, co w pełni oddaje uroczysty

1 Adresatem wiersza Szadurskiego był Dawid Zygmunt Pilchowski herbu Rogala - urodzony w Rutkiszkach w 1735, zmarł w Wilnie w 1803 r., jezuita, wykładowca i nauczyciel retoryki, autor wierszy okolicznościowych. W 1766 r. Pilchowski rozpoczął pracę w wileńskim Collegium Nobilium, gdzie uczył poetyki, przekładał Salustiusza i Senekę. W 1769 r. złożył profesję zakonną i z tej okazji ofiarował na bibliotekę kolegium znaczącą sumę (według niektórych źródeł było to 28000 zł, według innych - $16000 \mathrm{zl})$. Niewątpliwie wiersz Szadurskiego ma związek z tą donacją.

2 Wacław Gizbert Studnicki - historyk, bibliofil, kolekcjoner starych druków i archiwista, urodził się w Dyneburgu w 1874, zmarł na emigracji w Stanach Zjednoczonych w 1962 r. Był działaczem Polskiej Partii Socjalistycznej, więźniem carskim i emigrantem. Po 1906 r. pracował w „Dzienniku Wileńskim”, piśmie Narodowej Demokracji. Od 1908 r. kierował Archiwum Miejskim w Wilnie. Interesował się historią Wilna, badał ją i zbierał do niej materiały. Po wojnie wyjechał z Polski.

3 Tadeusz Wróblewski herbu Ślepowron - prawnik, historyk i bibliofil, wolnomularz, urodzony w Wilnie w 1858, zmarł w 1925 r. Był synem Eustachego i Emilii z Beniowskich Wróblewskich. W 1912 r. założył Bibliotekę im. Eustachego i Emilii Wróblewskich, którą systematycznie powiększano. Po śmierci fundatora placówkę przejęło państwo polskie. Dzisiaj zbiory Biblioteki Wróblewskich należą do Biblioteki Litewskiej Akademii Nauk. 
i właśnie okolicznościowy charakter podarunku. Tytulatura wypełnia całą pierwszą stronę odpisu. Umieszczony na błękitnym papierze czerpanym ze znakami wodnymi, obustronnie zapisany na złożonym arkuszu o wymiarach I9 na I7 cm tekst został ponadto ozdobiony ramą wykonaną $\mathrm{w}$ technice akwarelowej, przedstawiającą bramę tryumfalną. Składa się ona $\mathrm{z}$ dwóch symetrycznie rozmieszczonych po bokach błękitno-czerwonych kolumn w kształcie ostrosłupów o podstawie kwadratowej, zwieńczonych ozdobnymi złoto-brązowymi kulami o pofałdowanej powierzchni. Każda $\mathrm{z}$ kolumn wznosi się na sześciennej podstawie zbudowanej z ułożonych woluminów w ten sposób, że boki podstawy tworzą tomy stojące wobec siebie pod kątem prostym, zaś spód i wierzch tworzą tomy leżące. Księgi pomalowano na brązowo i czarno. Wierzchołki kolumn łączy łuk, zamykający zarazem całość od góry. W najwyższym jego punkcie została umieszczona złoto-brązowa korona. W tak obramowane pole wpisano tytuł wiersza oraz dedykację dla adresata. Ostrosłupowe kolumny przypominają kwinkunks (quincunx) - pięcioelementową figure geometryczną $\mathrm{z}$ czterema punktami w rogach podstawy i piątym umieszczonym pośrodku. Kwinkunks był modelem piramidy. Nakreślony w Aplauzie obraz bramy wspartej właśnie na dwóch piramidach symbolizował - w tradycji wolnomularskiej - doskonalenie się człowieka ${ }^{4}$. Wacław Gizbert Studnicki wprowadził tę symbolikę nieprzypadkowo - adresat, Tadeusz Wróblewski, należał przecież do grona znanych polskich wolnomularzy.

Kim był Ignacy Szadurski, którego nazwisko widnieje na odpisie wiersza? Nie mamy na jego temat, niestety, zbyt wielu dokładnych informacji. A co więcej - niewykluczone, że Studnicki przepisując tekst wiersza, pomylił się nie tylko co do imienia, ale wręcz osoby autora. Wszystkie bowiem wymienione w rękopisie tytuły wierszopisa - regenta kancelarii mniejszej litewskiej oraz chorążego inflanckiego - były przypisane Janowi Szadurskiemu herbu Ciołek, zmarłemu w I77I roku, o którym wiemy, że miał kontakty z wileńskimi jezuitami, że był posłem na sejmy i aktywnym uczestnikiem wydarzeń politycznych schyłku panowania Augusta III i pierwszej dekady rządów Stanisława Augusta. Jan Szadurski miał natomiast syna Ignacego, zmarłego w 1778 roku. W Ztotej księdze szlachty polskiej Teodora Żychlińskiego tenże Ignacy (tytułowany szambelanem królewskim) jest wymieniany jako Jan. Być może tutaj tkwi źródło niejasności: Jan i Ignacy - ojciec i syn mogli w odpisie sporządzonym przez Studnickiego zamienić się miejscami. Ale to nie koniec zagadek atrybucyjnych. Otóż w Archiwum Historycznym w Wilnie znajdują się pod sygnaturą F II35 Wiersze przy dokończeniu biblioteki w Collegium Nobilium Societatis Jesu fundowanej od w Bogu Wielebnego Jegomości

4 Zob. M. Pąkciński, Symbolika piramidy w rytuatach wolnomularstwa a filozofia Nietzschego (prolegomena), „Napis” 2010, seria 16, s. 421-433. 
$\mathrm{I} 76$

Księdza Dawida Pilchorwskiego. Jest to zbiór wierszowanych utworów autorstwa uczniów wileńskiego kolegium jezuickiego, napisanych z okazji zakończenia prac przy nowo ufundowanej bibliotece szkolnej. Pochwała biblioteki miała być przedstawiona jako zadanie $\mathrm{w}$ ramach ćwiczeń $\mathrm{z}$ retoryki. Wśród zachowanych utworów znajduje się także ten odpisany przez Wacława Gizberta Studnickiego, tyle tylko, że podpisany przez ucznia Alojzego Korkozowicza, a nie Szadurskiego 5 . Czy Studnicki pomylił się? Czy może o przyznaniu Szadurskiemu autorstwa wiersza zadecydowały jakieś inne względy? Tego, niestety, nie jesteśmy w stanie rozstrzygnąć. Jedno wszakże zastanawia - Wacław Studnicki był bardzo doświadczonym archiwistą i historykiem, więc taka pomyłka atrybucyjna byłaby doprawdy bardzo dziwna. Tak czy inaczej na laudacji ofiarowanej Tadeuszowi Wróblewskiemu autorem odpisanego wiersza na zawsze już pozostanie Ignacy Szadurski. I nam, przedstawiającym to literacko-plastyczne dziełko Studnickiego, wypada nazwisko Szadurskiego zachować.

Utwór pełni poczwórną funkcję okolicznościową. Po pierwsze, jest wierszem imieninowym, ofiarowanym Tadeuszowi Wróblewskiemu z wyrazami przyjaźni przez Wacława Gizberta Studnickiego i tym samym - pamiątką chwili o charakterze towarzyskim, a jednocześnie świadectwem wydarzenia historycznego. Po drugie, stanowi pochwałę biblioteki w ogóle, jako zbioru wiedzy oraz miejsca gromadzenia, podtrzymywania i przekazywania tradycji kultury. Po trzecie, jest pochwałą konkretnych zbiorów, gromadzonych przez Tadeusza Wróblewskiego. Założona przez niego biblioteka okazała się nie tylko „dziełem życia” i bezdyskusyjnym dobrem kultury polskiej, ale była również znakomitym przykładem wcielania w życie idei dobra, budowania wspólnoty narodowej i kulturowej opartej na tradycji humanistycznej. I po czwarte, jest także pochwałą i przypomnieniem biblioteki jezuickiego kolegium w Wilnie. Pochwałą - dodajmy - naprawdę w pełni sarmacką i oświeceniową zarazem, bo przedkładającą życie stateczne, dobrze osadzone w jednym miejscu ponad żywioł niebezpiecznych podróży. Biblioteka jako okno na świat to prawdziwie oświeceniowy koncept, jeden z tych, które miały urzeczywistnić postać nowoczesnego sarmaty.

Pomysł sporządzenia takiego aplauzu jest zabawą literacką, ale ma także wymowę poważnej laudacji - to świadectwo obecności kultury polskiej w Wilnie, a zarazem świadectwo roli książek w przestrzeni publicznej. Okolicznościowy wiersz Ignacego Szadurskiego (Alojzego Korkozowicza) z XVIII wieku okazał się znakomitym pretekstem dla uświetnienia okoliczności osadzonej w realiach

5 Zbiór wierszy bibliotecznych z Archiwum Historycznego w Wilnie przedstawia i wyczerpująco omawia Stanisław Roszak, osadzając utwory w kontekście dziejów nauczania retoryki w konwiktach jezuickich. Zob. idem, Koniec świata sarmackich erudytów, Toruń 2012, s. 112-116. 
początków wieku XX. Uobecnienie tak wielu postaci oraz instytucji - pamiętajmy bowiem o bibliotece jezuickiego Collegium Nobilium w Wilnie - które autor uwiecznił i pochwalił w wierszu, jest ze wszech miar godne podkreślenia i zapamiętania. Ta z pozoru błaha wędrówka tekstu przez stulecia wymownie świadczy o ogromnej wartości przypisywanej lekturze w świadomości Polaków żyjących zarówno w XVIII, jak i w XX wieku. Odpis sporządzony przez Studnickiego stał się wymowną klamrą pięknie spinającą wileńską bibliotekę jezuickiego konwiktu z książnicą założoną w Wilnie przez Tadeusza Wróblewskiego. W tym połączeniu i przypomnieniu mieści się jakaś symboliczna treść: ta pierwsza biblioteka została otwarta tuż przed pierwszym rozbiorem Rzeczypospolitej, u końca jej politycznego bytu, ta druga powstała w chwili budzących się nadziei na odzyskanie wolności.

Aplauz tryumfalny na s. patrona dzień Imci Panu Tadeuszowi Korwinowi z Wróblewa Wróblewskiemu, strażnikowi wileńskiej szubrawicyi ${ }^{6}$, fundatorowi Biblioteki imienia Eustachego i Emilyi Wróblewskich przez Wacława Gizberta Studnickiego ze starego manuskryptu przepisany ${ }^{7}$

I miast, i królestw ciekawością zdjęty

Ujrzenia, chciałem na krzywe okręty

Wpadłszy, świat obiec i zwiedziwszy całą

Ziemię, wiadomość powziąć doskonałą,

Co się gdzie w której dzieje części świata,

Gdzie ziemia w żyzność, gdzie w złoto bogata,

Jakie gdzie państwa i obywatele.

Lecz na co zda się trudów mi tak wiele?

Azaż tu nie mam Włocha i Anglika,

Hiszpana, Czecha i Portugalczyka?

Po cóż po Niemcach tłuc się i Szwajcarach?

I neapolskich daremnie Liparach $^{8}$ ?

6 Towarzystwo Szubrawców - stowarzyszenie działające w Wilnie w latach 1817-1822 oraz 1899-1914. Jego celem było piętnowanie nagannych moralnie zachowań w sferze publicznej. Szubrawcy słynęli z ostrego dowcipu, stosowania ironii i ataków o charakterze satyrycznym. Tadeusz Wróblewski (wolnomularz) reaktywował Towarzystwo w 1899 r. Szubrawcy spotykali się w jego mieszkaniu w Wilnie, przy ulicy Uniwersyteckiej.

7 Pozostawiam oryginalną, stylizowaną na dawną pisownię w nadanym przez Wacława Studnickiego tytule utworu dla podkreślenia jego uroczystej roli. Uwspółcześniono natomiast interpunkcję i rozwinięto skrótowy zapis tytulatury.

8 Lipary - należące do Włoch Wyspy Liparyjskie pochodzenia wulkanicznego położone są nieopodal Sycylii. 
Po co po górach, lasach, morskiej fali

I gdzie się słońcem czarny Murzyn pali

Mam latać? Po co zwiedzać Malabary9?

Meksyki? Zgoła świat nowy i stary?

Wszak to godnym [sic!] tu jest, jakbym był przytomny

Wszędy, i obiegł wkoło świat ogromny.

Znajduję wszystko w tej bibliotece,

Choć się nie kwapię ani stąd gdzie lecę.

Nie trzeba dalej, ujrzę ja tu wody,

Góry i miasta, i wszystkie narody,

Tu i monarchów, i ich znajdę kraje,

Poznam mieszkańców i onych zwyczaje.

Zgoła, gdy zechcę, oglądam świat cały,

I to, co wieki w prochach zagrzebały,

I to, co ziemia w swych wnętrznościach kryje,

I co w bezdennych morze nurtach myje.

Któż więc w tym szczupłym tyle zebrał Domu?

Nie powiem. Czemuż? Nie tajno nikomu.

Ignacy Szadurski

Regen[t kancelarii] W[ielkiego] X[ięstwa] L[itewskiego] Chor[ąży] Inflan[cki]

Skopiował na dzień 28 IXbra r. I9I2 w Wilnie z Wierszy przy dokończeniu Biblioteki $w$ Collegium Nobilium Societatis Jesu fundowaney od w Bogu wielebnego jegomości księdza Dawida Pilchowskiego Societatis Jesu Prefekta tegoż Collegium WW Ichmościów Panów Kawalerów tamże krasomowskiej i rymotworskiej sztuki uczacych się.

Napisane

Roku 1770

Wacław Gizbert Studnicki

SŁOWA KLUCzE: wiersz okolicznościowy, aplauz, biblioteka, kultura literacka na Kresach

9 Malabary (dzisiaj Malabar) - fragment południowo-zachodniego wybrzeża Indii nad Morzem Arabskim. Pod koniec XV w. dotarł tam Vasco da Gama. 


\section{Wojciech Kaliszewski}

\section{ECHO OF A PLEASANT FRIENDSHIP. A TRINKET IN VERSE FORM, RETRIEVED FROM A BRIEFCASE OF LONG-FORGOTTEN \\ MANUSCRIPTS}

The manuscript, retrieved from the archives of the Library of the Lithuanian Academy of Sciences, presents an occasional letter by a famous Lithuanian archivist and collector, Wacław Gizbert Studnicki, offered to the founder and benefactor of the Vilnius library, Tadeusz Wróblewski, for his name day. The main body of the letter is constituted by an occasional poem, re-written by Studnicki, dated 1770 and signed by Ingacy Szadurski, which is a praise of library collections.

KEY WORDS: occasional literature, praise, library, literary culture in Kresy 